\title{
Income shifting in the Spanish dual income tax
}

\author{
Julio López-Laborda \\ Universidad de Zaragoza, Saragossa, Spain \\ (julio.lopez@unizar.es) \\ Jaime Vallés-Giménez \\ Universidad de Zaragoza, Saragossa, Spain \\ (jvalles@unizar.es) \\ Anabel Zárate-Marco \\ Universidad de Zaragoza, Saragossa, Spain \\ (azarate@unizar.es)
}

\begin{abstract}
:
Based on a model of behavioural response to taxes, and using the Taxpayers Panel of the Institute of Fiscal Studies for the period 1999-2009, we analyse whether the dual nature of the Spanish Personal Income Tax (PIT), reinforced by the reform of the year 2007, has influenced taxpayers' behaviour, causing them to convert part of their "general income" (from labor, real estate or economic activities) into "savings income" (from movable capital or capital gains). We also extend the analysis of income shifting and study whether Spanish taxpayers also responded to the different tax treatment given to the two types of savings income (movable capital and capital gains) until 2007, transforming savings income from one type to another. The results of our study demonstrate three facts. First, Spanish taxpayers did respond to the different tax rates, shifting income from the general base to different forms of savings, especially capital gains. The highest-income individuals and the self-employed and business owners are the groups where this behaviour was most marked. Second, self-employed and business owners also turned income from movable assets into capital gains, guided by their different tax rates. And third, we have found signs of "anticipation" and "learning" effects caused by the 2007 tax reform. We believe that the results obtained will enrich the growing literature on income shifting.
\end{abstract}

KEYWORDS: tax planning, general income, savings income, income shifting, tax rate difference.

JEL CODES: H24, H31. 


\section{ACKNOWLEDGEMENTS:}

A version of this paper was presented to the XXII Encuentro de Economía Pública (Santander, 5-6 February 2015), in which it obtained the Encuentro de Economía Pública - Instituto de Estudios Fiscales Prize. The authors are grateful for the comments of the participants and, especially, those from Milagros Paniagua. The authors gratefully acknowledge the valuable comments on the paper of two anonymous referees and the editor of Fiscal Studies and the funding support of the Regional Government of Aragon and the European Regional Development Fund (Public Economics Research Group). Julio López-Laborda gratefully acknowledges the financial support from the Spanish Ministry of Economics and Competitiveness (Project ECO2016-76506-C4-3-R). The usual disclaimer applies.

\section{POLICY POINTS:}

- Dual income taxes, which tax savings income at lower rates than general income, encourage an income shifting strategy which has hardly been studied by the applied literature.

- Spanish PIT taxpayers plan the composition of their taxable base according to the taxation of each income source in three ways. They shift part of their revenues from the general base to that of savings, especially capital gains. They shift income from capital income to capital gains. And they shift income over time.

- Self-employed and business owners and higher-income individuals are the ones who most use these tax planning strategies.

- All these strategies generate inefficiencies and erode the progressivity of the tax system and revenue collection, and thus they must be taken into account when designing taxes. 


\section{Introduction}

A widespread practice of recent years in the majority of OECD countries is the adoption of specific treatments for capital income under synthetic income taxes. Despite the advantages the literature associates with dual income taxes (Boadway, 2004; Sørensen, 2005), in the Nordic countries, which have more than 20 years' experience in the field, there is a growing concern that a dual tax may incentivise tax avoidance through income shifting between tax bases. The different tax rates which can be applied to income depending on how it is obtained, as earned income or as capital income, mean that individuals are tempted to shift part of their returns from the general base to the capital base, in order to take advantage of a more favorable tax. This generates inefficiencies and erodes the progressivity of the tax system, and has caused the Nordic countries to adopt certain measures to avoid this behaviour, such as the distribution of business income between the tax base of labor and the tax base of capital.

Spanish Personal Income Tax (henceforth, PIT) has traditionally applied a lower tax rate to capital gains. Since 2007, this treatment extends to movable capital income. The aim of this paper is to analyse whether the dual nature of the PIT has influenced taxpayers' behaviour, causing them to convert part of their "general income" (from labor, real estate or economic activities) into "savings income" (from movable capital or capital gains). The options are varied. We will examine three examples. First, if employees are paid in kind in the form of company shares, up to a set limit, this payment in kind is exempt from PIT, and future returns on the shares will be taxed as savings income. Second, the self-employed and business owners can finance an investment with external resources and deduct the financial expenses, thereby reducing their general taxable income, and invest their own funds in savings income, which will be taxed at lower rates. And third, if the individuals invest in movable assets rather than real estate, they will pay lower taxes, given that income from the former is savings income, and from the latter, general income. In this paper we also extend the analysis of income shifting and study whether Spanish taxpayers also responded to the different tax treatment given to the two types of savings income (movable capital and capital gains) until 2007, transforming savings income from one type to another. This aspect has not been previously analysed in the literature.

The empirical exercise is performed using the Spanish Taxpayers Panel of the Institute of Fiscal Studies (IEF) for the period 1999-2009. The results of our study demonstrate 
three facts. First, Spanish taxpayers did respond to the different tax rates, shifting income from the general base to different forms of savings, especially capital gains. The highest-income individuals and the self-employed and business owners are the groups where this behaviour was most marked. Second, self-employed and business owners also turned income from movable assets into capital gains, guided by their different tax rates. And third, we have found signs of "anticipation" and "learning" effects caused by the 2007 tax reform. We believe that the results obtained will enrich the growing literature on income shifting.

Related literature. Studies of income shifting between bases have focused on several issues: The form of organisation chosen by entrepreneurs (as Gordon and MacKieMason, 1994, and Gordon and Slemrod, 2000, for the USA; Domínguez-Barrero et al., 2005, for Spain; De Mooij and Nicodème, 2008, for several European countries; and Thoresen and Alstadsaeter, 2010, for Norway); the choice of remuneration regime for business owners (such as Kari, 1999; Fjaerli and Lun, 2001; Lindhe et al., 2002 and 2004; Alstadsaeter and Jacob, 2016; and Harju and Matikka, 2016 a and 2016 b, for the Nordic countries); and income shifting between spouses (as in Stephens and WardBatts, 2004, for the UK).

Studies of income shifting over time have focused on when dividends are paid out (Chetty and Saez, 2005, for the USA; Kari et al, 2008, for Finland; Jacob and Jacob, 2012, for 25 OCDE countries; le Maire and Schjerning, 2013, for Denmark) and, above all, on when capital gains are realised (notable works include studies of the USA by Poterba, 1987; Auerbach et al., 1998; Reese, 1998; Poterba and Weisbenner, 2001; Ivkovíc et al., 2005; and Dai et al., 2008; and the more recent work of Daunfeldt et al., 2010, and Jacob, 2016a, for Sweden). ${ }^{1}$ This last research avenue has proliferated in the last two decades and provides sufficient empirical evidence of the "lock-in" effect which high tax rates provoke in capital gains.

However, income shifting between tax bases of the PIT has hardly been studied empirically and is unknown in Spain, where only the theoretical contributions of Domínguez-Barrero and López-Laborda (2003, 2008) are to be found. ${ }^{2}$ Sørensen (2010) performs an interesting theoretical analysis of the question for the Nordic countries and,

\footnotetext{
1 See the recent surveys about income shifting by Saez et al. (2012) and Alstadsæter and Jacob (2012).

${ }^{2}$ A very preliminary approach to the problem which concerns us in this study can be found in MorenoCepas (2012).
} 
as far as we are aware, Pirttilä and Selin (2011) are the only authors to provide empirical evidence on this phenomenon. They studied Finland's 1993 tax reform, which lowered marginal taxes on capital income for some, but not all, taxpayers. For that reason, their work analyses the different responses of a treatment group (self-employed) and a control group (employees) to the introduction of a dual tax which taxed all savings income neutrally, finding evidence that the self-employed shifted income from the general base to the savings base.

Thanks to the richness of information in the database we worked with, and to the fact that the changes in tax rates of the 2007 reform made tax planning feasible for all Spanish taxpayers, whatever their income level, we were able to use a different scenario and methodology than Pirttilä and Selin (2011) to study these questions. The Spanish tax reform is therefore particularly suitable for examining the impacts of a dual tax reform, and lets us offer richer results than those obtained in Pirttilä and Selin (2011).

Our article also relates closely to the line of research cited above, which analyses the choice of remuneration regime for business owners (wages or dividends), especially the work of Harju and Matikka (2016a). These authors analyse income shifting in a very similar way to our approach here, using the tax rate differential between wages and dividends to measure income shifting between them after the 2005 reform in Finland.

Outline of the paper. The paper is structured as follows. In the next section we present the model of behavioural responses to taxes which constitutes the theoretical basis of our research. The third section describes the evolution of the taxation of general and savings income in the Spanish PIT since 1999, and how the reform of 2007 introduced new incentives to shift income between the two bases. In this section we also analyse the fiscal data supplied by the Ministry of Public Finance and Public Administrations (MINHAP); these already provide clues concerning some taxpayers' tax planning strategies, which we shall subsequently test empirically. In the fourth section we describe the model which we shall estimate, the dependent and independent variables and the database employed, and in the fifth section we explain the estimations performed and discuss the main obtained results. The paper concludes with a section of final considerations. 


\section{The model}

To analyse the incentives for taxpayers to decide the composition of their income based on the different taxes charged on its components, we will extend a simple static model of income shifting developed by Piketty and Saez (2013), Piketty et al. (2014) and Harju and Matikka (2016a). ${ }^{3}$

Individual $i$ obtains general income, $z_{g}$ (e.g., labor income) and two types of savings income: movable capital income, $z_{m c}$ (e.g., dividends and interests) and capital gains, $z_{c g}$. General income is subject to a tax rate $t_{g}$. Movable capital income is subject to a tax rate $t_{m c}$, and capital gains to a rate of $t_{c g}$. It fulfills $t_{c g} \leq t_{m c} \leq t_{g}$. Total taxable income of the individual $i$ is $z=z_{g}+z_{m c}+z_{c g}$. Individuals can, at some cost, shift income between the three types of income, guided by the lower taxation of movable capital income, and especially, of capital gains.

The budget constraint of the individual $i$ is the following:

[1] $\quad c=z-t_{g}\left(z_{g}-a_{1}-a_{2}\right)-t_{m c}\left(z_{m c}+a_{1}-a_{3}\right)-t_{c g}\left(z_{c g}+a_{2}+a_{3}\right)=$ $z_{g}\left(1-t_{g}\right)+z_{m c}\left(1-t_{m c}\right)+z_{c g}\left(1-t_{c g}\right)+a_{1}\left(t_{g}-t_{m c}\right)+a_{2}\left(t_{g}-t_{c g}\right)+$ $a_{3}\left(t_{m c}-t_{c g}\right)$

Where $c$ is consumption and $a_{j}$ represents the amount of income shifted between the tax bases in response to the differences in tax rates, with $j=1$ denoting the strategy of shifting from $z_{g}$ to $z_{m c} ; j=2$, shifting from $z_{g}$ to $z_{c g}$; and $j=3$, from $z_{m c}$ to $z_{c g}$. The utility function of individual $i$ is:

$$
u_{i}\left(c, z, a_{j}\right)=c-\theta_{g i}\left(z_{g}\right)-\theta_{m c i}\left(z_{m c}\right)-\theta_{c g i}\left(z_{c g}\right)-\sum_{j=1}^{3} \phi_{j i}\left(a_{j}\right)
$$

where $\theta_{\cdot i}(\cdot)$ is the cost of producing each type of taxable income, and $\phi_{j i}\left(a_{j}\right)$ is the cost of income shifting between types of income. Cost functions are convex and increasing in $z_{g}, z_{m c}, z_{c g}$ and $a_{j}$, respectively. ${ }^{4}$

The first-order conditions of the maximization problem for individual $i$ are as follows:

\footnotetext{
${ }^{3}$ See also Slemrod (2001) and Domínguez-Barrero and López-Laborda (2001). For a recent dynamic approach, see Saez and Stantcheva (2016).

${ }^{4}$ Slemrod (2001) and Domínguez-Barrero and López-Laborda (2001) consider that the cost of income shifting also depends inversely on the income obtained by the individual. Slemrod (2001) refers to this relationship as the "avoidance-facilitating" quality of true income. This assumption significantly alters the first-order conditions reflected in [3a], [3b] and [3c].
} 


$$
1-t_{g}=\theta_{g i}^{\prime}\left(z_{g}\right)
$$

$$
1-t_{m c}=\theta_{m c i}^{\prime}\left(z_{m c}\right)
$$

[3c] $\quad 1-t_{c g}=\theta_{c g i}^{\prime}\left(z_{c g}\right)$

[4a] $\quad t_{g}-t_{m c}=\phi_{1 i}^{\prime}\left(a_{1}\right)$

[4b] $\quad t_{g}-t_{c g}=\phi_{2 i}^{\prime}\left(a_{2}\right)$

$$
\text { [4c] } \quad t_{m c}-t_{c g}=\phi_{3 i}^{\prime}\left(a_{3}\right)
$$

Equations [3a], [3b] and [3c] reflect that taxable income is an inverse function of tax rate. Equations [4a], [4b] and [4c] show that income shifting is an increasing function of tax rate differences. Consequently, movable capital income (capital gains) reported by an individual will depend on i) the own tax rate applied to this income, ii) the difference between the tax rate on movable capital income (capital gains) and the tax rate on general income, iii) the difference between the tax rate on movable capital income and the tax rate on capital gains, and iv) the cost of transforming one type of income into another. Based on this simple model, in the following sections we shall try to empirically test whether these strategies occurred in Spain in the period 1999-2009.

\section{The dual character of the Spanish PIT and taxpayers' tax planning}

On 1 January 2007 a new reform of the PIT came into force in Spain which took further steps towards dualisation of the tax. Until that date, only capital gains generated in a period of over one year were taxed at a constant rate, which has varied with the successive tax reforms. ${ }^{5}$ The remaining income was taxed under the general tax schedule, which has also undergone modifications over the years, in both the number of brackets and the minimum and maximum tax rate. In 2007, certain movable capital income came to be taxed at the same constant rate as capital gains generated in a period of over one year. In Table 1 we summarise the evolution of savings income taxation for 1999-2009, which is the period for which we shall undertake the empirical analysis.

\footnotetext{
5 This constant tax rate in 1999 was higher than the minimum marginal rate of the general tax schedule. In 2000 and 2003 it was reduced and equated that minimum. In 2007 it was increased, but was fixed below the general minimum rate, which underwent a sharp increase. In 2010 it rose once more and was replaced by a schedule of few brackets of increasing rates which, although at first were lower than the minimum rate of the general schedule, by 2012 were greater.
} 
Table 1: Nominal tax rates for savings income in Spain, 1999-2009 $\left({ }^{*}\right)$

\begin{tabular}{|l|c|c|l|c|c|c|}
\hline & $\begin{array}{c}\text { Movable capital: } \\
\text { Interests, dividends, } \\
\text { insurance }\end{array}$ & $\begin{array}{c}\text { Movable capital: } \\
\text { Other income }\end{array}$ & \multicolumn{2}{|c|}{$\begin{array}{c}\text { Capital gains } \\
\text { generated in less than }\end{array}$} & \multicolumn{2}{|c|}{$\begin{array}{c}\text { Capital gains } \\
\text { generated in more } \\
\text { than }\end{array}$} \\
\hline $\mathbf{1 9 9 9}$ & $18-48 \%(6)$ & $18-48 \%(6)$ & 2 years: & $18-48 \%(6)$ & 2 years: & $20 \%$ \\
\hline $\mathbf{2 0 0 0}$ & $18-48 \%(6)$ & $18-48 \%(6)$ & 1 year: & $18-48 \%(6)$ & 1 year: & $18 \%$ \\
\hline $\mathbf{2 0 0 1}$ & $18-48 \%(6)$ & $18-48 \%(6)$ & 1 year: & $18-48 \%(6)$ & 1 year: & $18 \%$ \\
\hline $\mathbf{2 0 0 2}$ & $18-48 \%(6)$ & $18-48 \%(6)$ & 1 year: & $18-48 \%(6)$ & 1 year: & $18 \%$ \\
\hline $\mathbf{2 0 0 3}$ & $15-45 \%(5)$ & $15-45 \%(5)$ & 1 year: & $15-45 \%(5)$ & 1 year: & $15 \%$ \\
\hline $\mathbf{2 0 0 4}$ & $15-45 \%(5)$ & $15-45 \%(5)$ & 1 year: & $15-45 \%(5)$ & 1 year: & $15 \%$ \\
\hline $\mathbf{2 0 0 5}$ & $15-45 \%(5)$ & $15-45 \%(5)$ & 1 year: & $15-45 \%(5)$ & 1 year: & $15 \%$ \\
\hline $\mathbf{2 0 0 6}$ & $15-45 \%(5)$ & $15-45 \%(5)$ & 1 year: & $15-45 \%(5)$ & 1 year: & $15 \%$ \\
\hline $\mathbf{2 0 0 7}$ & $18 \%$ & $24-43 \%(4)$ & & $18 \%$ & $18 \%$ & $18 \%$ \\
\hline $\mathbf{2 0 0 8}$ & $18 \%$ & $24-43 \%(4)$ & & $18 \%$ & $18 \%$ \\
\hline $\mathbf{2 0 0 9}$ & $18 \%$ & & & & $18 \%$ \\
\hline
\end{tabular}

(*) Number of brackets of the tax schedule appears in parentheses.

Source: by the authors.

In 2007, capital gains generated in less than one year and movable capital income (dividends, interest and income from insurance and capitalisation operations), which until then had been taxed at the general tax schedule, came to be taxed at a constant rate of $18 \%$. Only movable capital income derived from intellectual and industrial property, together with that from the provision of technical assistance, from the renting of movable property, businesses or mines, from subletting and from leasing image rights (to all of which we shall term "other income from movable capital") continued to be taxed at the general tax schedule. ${ }^{6}$

In this way, the 2007 reform proved harmful for all capital gains generated in over one year, since their tax rate was increased by three percentage points, from 15 to $18 \%$. Regarding the general tax schedule, the maximum marginal tax rate was reduced by two

\footnotetext{
${ }^{6}$ In 2013 and 2014 capital gains generated in less than one year reverted to forming part of the general taxable base, although since 2015 they have been again taxed as savings income.
} 
percentage points, from $45 \%$ to $43 \%$, but the minimum was raised by nine percentage points, from 15 to $24 \%{ }^{7}$

Changes in tax rates introduced by the 2007 reform opened the way to greater possibilities for income shifting from the general to the savings base, for two reasons. First, there were more income sources which due to the reform came to be taxed at a constant tax rate, one lower than the minimum general tax rate. Second, the reform meant all taxpayers, whatever their income level, now had the option of undertaking such tax planning. Until then, taxpayers in the first bracket of the tax schedule had no incentive to adopt this strategy, since for them there was no difference between their marginal tax rate for general income and for savings. ${ }^{8}$ As income rose, the gap progressively increased until it reached 30 percentage points for taxpayers in the highest brackets. In turn, after the reform, all taxpayers, including those in the lowest brackets, were able to benefit from the strategy of income shifting between tax bases, since the gap between the marginal tax rate for general income and that for savings ranged from 6 percentage points for the lowest income taxpayers to 25 percentage points for the richest (table 1).

Statistics published by the MINHAP show the size of the various components of the taxable base by income levels. This information shows that the weight of movable capital income and capital gains generated in over one year clearly increase with the taxpayer income. By way of illustration, Figure 1 presents data for the year 2006, although the same pattern is reproduced for any year of the period. ${ }^{9}$

\footnotetext{
${ }^{7}$ The Autonomous Communities (Spanish regions) have powers to modify the general schedule that is applied in their territory, but until recently they have hardly used them.

${ }^{8}$ As shown in Table 1, in 1999 this gap was negative, by two percentage points, for the lowest income taxpayers, and reached 28 percentage points for the richest taxpayers.

${ }^{9}$ The figures for other years are available to the interested reader on request.
} 
Figure 1: Structure of the taxable base by income brackets. Spanish PIT 2006

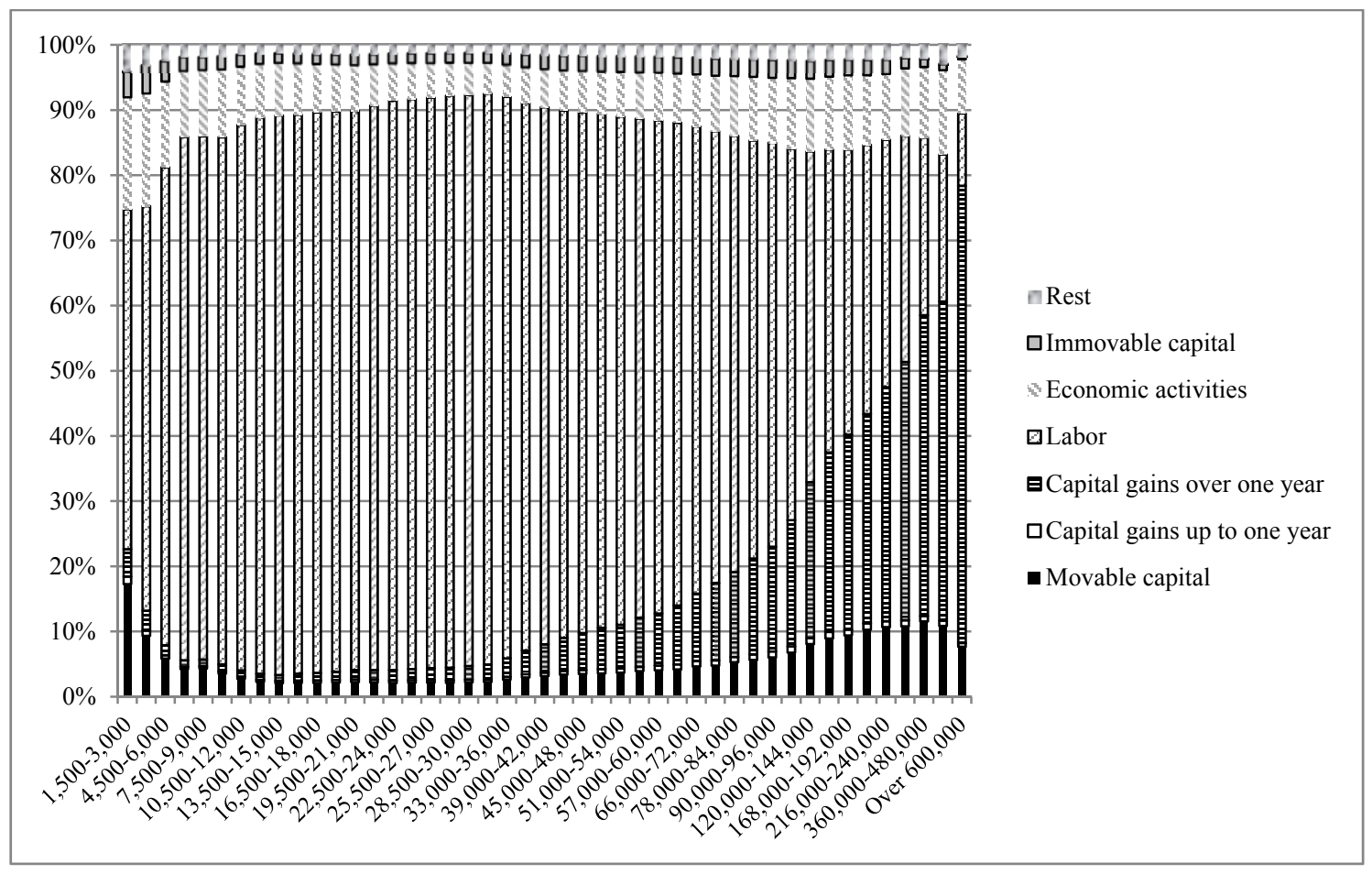

Source: Authors' elaboration, from General Directorate of Taxes (2009:91-92).

If we observe the evolution over time of the weights of the taxable base components, we can state that PIT taxpayers do indeed perform tax planning. Figure 2 shows that in the two years prior to the reform, the weight of movable capital income (black line) gradually increases, behind which there may be a strategic organisation of wealth, that is to say, anticipation by taxpayers of the imminent and generally favorable tax reform affecting this type of income, which was already known in 2005. However, such income acquired greater weight in 2007 and 2008, that is to say, once the favorable tax rate of $18 \%$ was already in force, which appears to reveal a learning effect by taxpayers of the advantages of the reform.

The behaviour varies according to income levels. Two years prior to the reform, movable capital income appears to lose weight in the richest taxpayers' tax base. This fact may indicate that these taxpayers delayed the decision to report movable capital income and waited until this income received a much more favorable tax treatment from 2007 onwards, which is when it gains a greater (and increasing) share in their total tax base. In the remaining income levels, movable capital income slightly increased its 
presence in the two years prior to the reform, despite the fact that after it taxpayers would pay taxes at a constant and generally lower tax rate. This behaviour may suggest that taxpayers reorganised their assets before the reform.

Figure 2: Evolution of the weight of movable capital income in the tax base, by income brackets

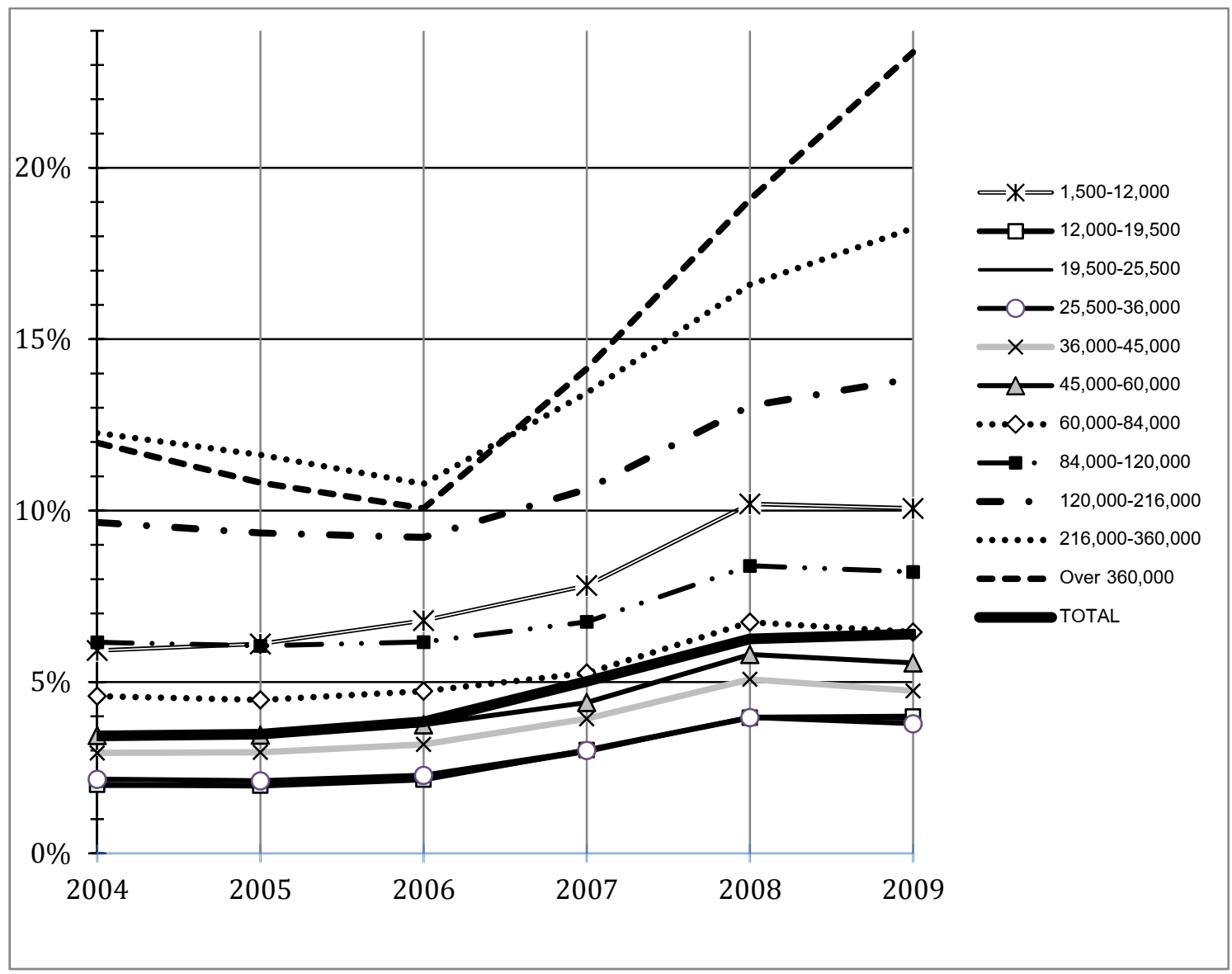

Source: By the authors, based on the General Directorate of Taxes' statistical publications for 2004 to 2009.

With regard to capital gains, Figure 3 shows that in 2006, when the immediate increase in the taxation of capital gains generated in over one year (the most important in the tax base according to Figure 1) became known, capital gains increased their weight in the tax base (unbroken black line). According to the General Directorate of Taxes (2013:82), the underlying causes of this increase were on the one hand, the favorable 
behaviour of the housing market and of the stock markets, and on the other, anticipation of the sale of investment funds to avoid the immediate tax increase of the 2007 reform.

In contrast, the weight of capital gains in total income decreased in 2007, 2008 and 2009 since, as we have seen, part of them were brought forward to the year prior to the reform, and additionally a lock-in effect could have occurred, in which capital gains were not realised during the period 2007-2009 probably due to the favorable taxation of dividends and interests from 2007 onwards. From then on, the poor behaviour of the housing and stock markets (General Directorate of Taxes, 2013: 82-3), as shown in the figure by broken lines, also played a role, although it became less significant over time.

Figure 3: Evolution of the weight of capital gains generated in over one year*

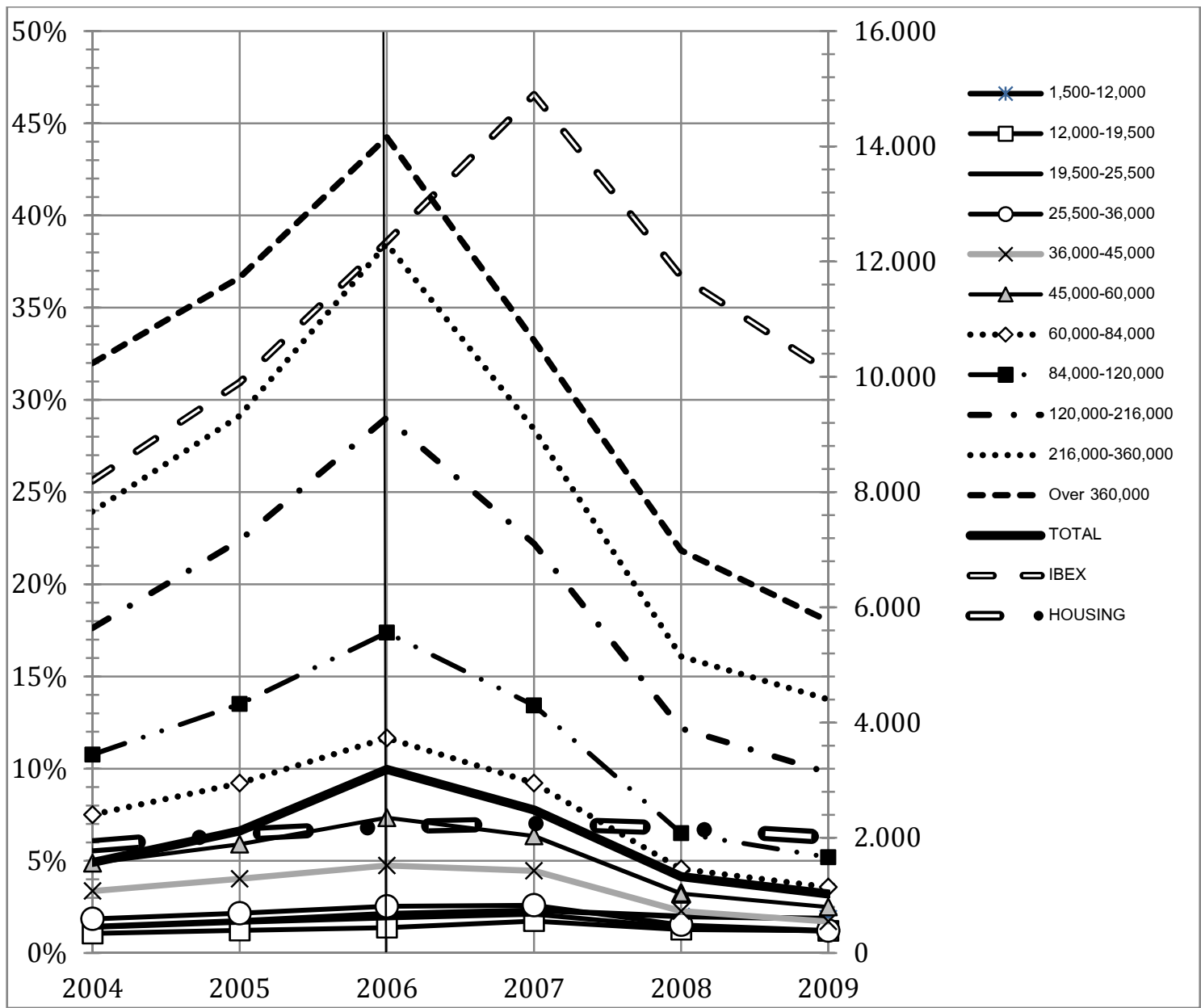

*The information shown by the graph since the year 2007 also includes capital gains generated in up to one year, since the Taxpayers Panel of the IEF does not provide disaggregated information on capital gains by their period of generation, as all are taxed in the same way. In any case, capital gains generated in up to one year had very little weight until the year 2006, and would probably increase following the reform, due to more favorable tax treatment. The graph also shows the evolution of the IBEX-35 and of the average price of second-hand housing.

Source: By the authors, based on the General Directorate of Taxes' statistical publications for the years 2004 to 2009. 
It appears, therefore, that taxpayers reacted to changes in the taxation of capital gains generated in over one year by modifying the timing of realisation - specifically, shifting it from the fiscal years 2007, 2008 and 2009 to the fiscal year 2006, due to more favorable taxation. By income brackets, the richest taxpayers brought forward capital gains to 2006 more often than lower income taxpayers, and for them the weight of capital gains also fell more sharply following the reform.

\section{Empirical approximation: specification and database}

In this section and the next, we shall econometrically test the hypothesis that the composition of the Spanish PIT taxpayers' tax base is affected by the difference between general and savings income tax rates as well as between movable capital income and capital gains tax rates. As previously mentioned, the exercise will be performed using the IEF's Spanish PIT Taxpayers Panel for the period 1999-2009.

As seen in the third section, the treatment of the diverse savings income (movable capital and capital gains) has changed over time, such that only from 2007 onwards do they receive a unitary treatment; and, furthermore, the weight of each category of savings income in total income has evolved differently over time. Consequently, we shall estimate two separate models for movable capital income and capital gains in order to determine whether taxpayers display differentiated behaviour between the two types of income. The model to be estimated for movable capital income is the following:

And for capital gains:

$$
\text { Capitalgains }_{i t}=\alpha+\delta X_{i t}+\gamma Z_{i t}+u_{i t}
$$

where Movablecapital ${ }_{i t}$ is the weight of this income reported each year in the total taxable base, Capitalgains it $_{\text {is }}$ the weight of realised capital gains in the taxpayer's total tax base, $X_{i t}$ are the variables of interest, and $Z_{i t}$ the control variables.

Next, we describe in some detail the dependent and independent variables included in the above specifications. The description and the expected effect of each variable are 
listed in Table A1.1 of Annex. Table A1.2 presents the main descriptive statistics of the variables.

\subsection{Endogenous variables}

We have taken as dependent variable the weight of movable capital income in the taxpayer's total tax base (Movablecapital) ${ }^{10}$ on the one hand, and the weight of capital gains in total taxable income (Capitalgains) ${ }^{11}$ on the other. Our aim is to see whether taxpayers can reorganise their income so it is obtained as one of these two forms of savings income rather than as general income or the other type of savings income, or modify the time when they materialise this income, in response to a tax change. An increase in these endogenous variables could have happened without even varying savings income (due to a fall in general income), or by increasing both savings and general income (depending on the proportion in which each is performed). However we consider that these variables constitute a good proxy for the income shifting between bases which we wish to measure, since they capture the taxpayer's tendency or resistance towards generating savings income, whether in the form of capital gains or movable capital, in lieu of other income. If the weight of savings income increases, logically that of other income must decrease.

\footnotetext{
${ }^{10}$ Savings income derived from mobile capital includes all movable capital income, that is to say, not only dividends, interests and income derived from life insurance and capitalisation operations, which from 2007 onwards have been taxed at a constant tax rate; but also "other movable capital income" which has always been taxed in the general schedule because, until 2004, the Taxpayers Panel did not distinguish it from the remaining movable capital income. Although the amount of taxed dividends differs according to the mechanism employed to eliminate double taxation, we shall not take it into account when measuring tax rates, because in 2007 the full tax imputation system stopped being used as a corrective mechanism of the double taxation of dividends. This was replaced by the exemption system, which covered the first $€ 1,500$ obtained by the taxpayer. We do not take into account the movable capital income from the "Special Scheme for Attribution", because the data are not available for 1999. We have also removed the observations for which movable capital income is negative, in order to avoid negative values for this variable.

${ }^{11}$ Savings income derived from capital gains includes all capital gains, independently of their origin (sales of properties or other), since until 2006 this disaggregation was unknown; and also independently of the time in which they were generated, since differentiation according to the time of generation is not always equal ( 1 or 2 years) and, furthermore, has been unknown since 2007 . We do not discount compensations of capital losses from prior years, since we are trying to see whether the taxpayer decides to generate capital gains or other income types each year. We have removed the observations for which the capital gains are negative, with the objective of avoiding the dependent variable also being negative.
} 


\subsection{Explanatory variables}

As explanatory variables we have included, in addition to our interest variables, a set of control variables which are intended to reflect individuals' observable characteristics and the time trend. Additionally, in the model which estimates movable capital income, the endogenous variable is lagged one period, in order to observe the dynamic pattern of taxpayers' behaviour, given that movable capital income reported in one year will also depend on the investment made in movable capital in previous years. However, in the model of capital gains the capital realised in one year will not depend on that realised in previous years.

\subsubsection{Variables of interest}

\section{Marginal benefit from savings income}

The main explanatory interest variable is the marginal benefit derived from the reduction of taxation for savings income. The greater this marginal benefit, the more incentives individuals will have to undertake tax planning, increasing the weight of savings income in their total income.

We must take into account that the marginal benefit derived from the reduction of taxation for savings income is different for capital gains and for movable capital income, and thus it must be defined and calculated differently. When we explain the weight of capital gains in the taxpayer's total tax base, the marginal benefit derived from the reduction in taxation for capital gains is calculated for each taxpayer as the difference $t_{g C G}-t_{s C G}$. Defining $t_{g C G}$ as the marginal tax rate at which capital gains for each taxpayer would be taxed each year if they had been obtained as general income and were taxed, consequently, in the general tax schedule; and $t_{S C G}$ as the nominal tax rate at which capital gains generated in more than one year were taxed according to the regulations of each year.

When we estimate the weight of movable capital income in the total tax base, we shall calculate the marginal benefit derived from the reduction of taxation for movable capital income for each taxpayer as the difference $t_{g M C}-t_{s M C}$. To do this, we have defined $t_{g M C}$ as the marginal tax rate at which movable capital income would be taxed each year for each taxpayer if it had been obtained as general income and taxed in the general tax schedule. $t_{S M C}$ is the marginal tax rate at which movable capital income is taxed according to the regulations of each year. As until the 2007 reform this income was 
taxed in the general schedule, there was no tax incentive to shift income from the general base to movable capital income, the variable $t_{g M C}-t_{S M C}$ therefore taking the value of zero.

According to our theoretical model, there may also be incentives for the taxpayer to shift income between movable capital income and capital gains. For this reason, when we estimate the weight of capital gains in an individual's total taxable income, we include as an explanatory variable the difference $t_{s C G}{ }^{M C}-t_{s C G}$, calculated for that individual. $t_{s C G}{ }^{M C}$ would be the tax rate applied to the individual's capital gains if taxed as movable capital income, and $t_{s C G}$ the previously defined nominal rate for capital gains. The larger this difference, the greater the incentive for the taxpayer to change movable capital income to capital gains, and thus, the higher the value of the endogenous variable, Capitalgains.

Similarly, when we explain the weight of movable capital income for each taxpayer, we could include the explanatory variable $t_{S M C}{ }^{\mathrm{CG}}-t_{S M C}$, where $t_{S M C}{ }^{\mathrm{CG}}$ is the tax rate applied to the individual's movable capital income if taxed as capital gains and $t_{S M C}$ the real tax rate applied to their movable capital income, as defined above. However, we have not included this variable $\left(t_{S M C}{ }^{\mathrm{CG}}-t_{S M C}\right)$, due to its high correlation with $\left(t_{g M C}-t_{S M C}\right) .{ }^{12}$

\section{Real response}

As our theoretical model also shows, the savings income reported each year depends on the tax rate on savings, so the model for estimating Capitalgains includes the variable $t_{s C G}$, as previously defined. As the movable capital income reported in a given year really depends on the movable capital supplied that year and the previous years, it will also depend on the tax rate applied to that income that year and the previous years. For this reason, the model to estimate Movablecapital includes a variable $t m_{s M C}$, which is the three-year moving average (the current year and the previous two years), ${ }^{13}$ of the tax rate applied to the individual's movable capital income.

To avoid endogeneity problems, all tax rates have been instrumented, as usual, using the income obtained by each taxpayer in 1999, the first year in the sample.

\footnotetext{
${ }^{12}$ Correlations between variables can be seen in Table A1.3 of Annex.

${ }^{13}$ We have taken a three-year moving average so as not to lose too many observations.
} 


\section{Anticipation of the reform and learning}

We are also interested in identifying whether the taxpayers anticipated and learned from the 2007 reform, and, therefore, if they have shifted income over time, in response to that reform. We will approximate these anticipation and learning effects using some of the time dummy variables (year200t, with $t=1,2 \ldots, 8$ ) we included in the model to capture the time fixed effects, which are the same for all individuals.

In 2005 it was already known that movable capital income which consisted of dividends, interests and insurance income would come to be taxed at a constant tax rate from 2007 on, so a positive sign for the time dummies year2005 and year2006 could indicate that the taxpayers anticipated the tax reform and reorganised their assets to reduce the tax burden. It would also be reasonable that the anticipation effect of the reform to be higher in 2006, closer to the date of its coming into force, so the coefficient of year2006 should be greater than that of year2005. However, as it was not known until 2006 that capital gains generated over one year were to be taxed at three percentage points above their previous tax rate, this income could not have been shifted in 2005. Thus, in the case of capital gains, we only expect significant positive effects for the dummy year2006.

Similarly, if taxpayers had been consistent with their planning strategies, the coming into force of the new tax rates should have significantly raised movable capital income, which had been especially favored since 2007, and reduced capital gains, either because they were brought forward and were realised in 2006, or because they were slowed down in the early years of the reform, given their comparatively less favorable taxation. We can approximate the measurement of these learning effects with the time dummies year2007 and year2008, expecting to obtain a positive coefficient for both when we estimate movable capital income, and a negative one when we estimate capital gains. Also, a greater coefficient for year2008 could be indicating that taxpayers did indeed learn from the reform and reacted to it more in 2008, by which time they would have been fully aware of the changes brought about by the reform already in force. It must be borne in mind that although the transparency of the tax measures is high, many taxpayers may not be aware of the tax changes until the time comes to file their tax return (or may even remain completely unaware of them). 


\subsubsection{Control variables}

\section{Opportunity to plan}

We incorporate the "opportunity" for individuals to plan how to obtain their income as the first control variable. The empirical literature (Auerbach and Siegel, 2000; Daunfeldt et al., 2010; Saez et al., 2012, Jacob, 2014, and Alstadsæter and Jacob, 2016) shows that the richest taxpayers react most to tax changes. Furthermore, higher income taxpayers will have better access to tax planning techniques. For that reason, we have interacted taxpayer income (Income) with the tax rate difference variable, in order to see if, for a given tax rate difference, income shifting from the general base increases as income levels increase. The variable Income is constructed by adding the gross income from labor and movable and immovable capital, the net income from economic activities and imputed income.

As in the literature, we also consider that self-employed and business owners have greater possibilities of performing tax planning strategies. They can decide, on the basis of taxation, to invest their profits in the same business, so they can then generate new profits which are taxed as income from economic activities in the general tax schedule, or to invest them in assets which generate savings income and which can be taxed at a lower rate. They can also finance an investment from external resources and deduct the financial expenses, thereby reducing their general taxable income, and use their own funds to invest in movable capital or in future capital gains, which will be taxed as savings income at lower rates. Consequently, and to capture this planning opportunity, we have constructed a dummy variable (Selfemployed) which takes the value of 1 if the taxpayer is self-employed or business owner and 0 otherwise, and interacted it with the tax rate difference variable, to see whether, for a given tax rate difference, the selfemployed and business owners shift more income from the general base to the savings base. We have also included the weight of income from self-employed and business owner in the taxpayer's total income as an explanatory variable (WeightEA), ${ }^{14}$ in both the current and the previous fiscal year, since income reorganisation may not be immediate, but instead take some time.

\footnotetext{
${ }^{14} \mathrm{We}$ assign to this variable the value of 0 when that income is negative, to avoid the weight in total income also being negative.
} 


\section{Economic needs}

Other control variables which we have included in the econometric specifications refer to the economic burdens of the individual, since greater economic need can affect the individual's savings income. As proxies of these economic burdens we have considered, on the one hand, family burden (Familyburden), which we have estimated from the personal and family amounts which are exempt from taxation (called minimums), including the minimums for descendants, ascendants and disability; and, on the other hand, the weight of the mortgage paid each fiscal year (Mortgageburden) in the taxpayer's income, which we have estimated on the basis of the amount of the tax credit for investment in the main home.

\section{Other control variables}

We have also tried to test whether savings income differs by geographic zones, due to their different productive structure. We suggest the possibility that the great weight of the construction and tourist sectors in the Mediterranean coastal zone favors savings income. To test this, we have included a dummy variable (Mediterranean) which takes the value of 1 if the taxpayer lives in a province of the Mediterranean coast and 0 otherwise; a positive effect is expected.

Given that higher housing prices also influence both the amount of capital gains and decisions on when to realise them, we have included the evolution of the average price of second-hand homes in the country as a whole (Phousing) in the estimations of capital gains, lagged by one period to reflect the fact that house sales are not immediate. We expect a positive sign for this variable.

Additionally, we have considered the age of the individual (Age) as an explanatory variable. According to the life cycle models of consumption and savings (Attanasio and Browning, 1995; Carroll, 1997; Gourinchas and Parker, 2002; Gomes and Mochaelides, 2005; Browning and Lusardi, 1996; Attanasio and Weber, 2010; Daunfeldt et al., 2010), when individuals are young they tend to save as a precaution, faced with uncertain employment situations, and thus are less prone to realise capital gains. When they are mature they save for retirement age, and thus also tend not to generate such income. In turn, when they reach retirement age they consume the saved income, although they may wish to leave an inheritance, and it is then that capital gains are usually realised. 
The expected effect of the age is then positive for capital gains and negative for movable capital income

Lastly, we have also included in the model marital status (Status: married $=1$; single $=0$ ), gender (Gender: male $=1$; female $=0$ ), size of the municipality in which the taxpayer lives (Pop), and a trend variable (Trend), with a priori indeterminate signs.

\subsection{Database}

The database we shall use to undertake the analysis is the PIT Taxpayers Panel for the period 1999-2009, which was compiled by the IEF on the basis of PIT returns supplied by the State Tax Agency (AEAT) (Onrubia et al., 2011; Onrubia et al., 2012). It is an expanded panel, in which each annual sample is representative of the Spanish population filing a PIT return that year. More specifically, we have used the file called "principal", where the unit of observation is the tax return. This lets us work with nearly a million observations. We have not included, therefore, the returns of spouses who pay tax individually (and are included in the "spouses" file), as we think they will contribute nothing to the investigation. Although spouses may redistribute income to each other to take advantage of separate taxation (López-Laborda and Zárate, 1999), this strategy is outside the scope of the present study.

The panel is not balanced, since some taxpayers die and others cease filing returns because their income has dropped beneath the minimum income threshold to do so; this requires the selection of a suitable estimation technique for non-balanced panels.

\section{Estimation and results}

In accordance with conventional assumptions, the best unbiased linear estimators are those obtained when employing ordinary least squares, as long as the errors are independent of each other and are identically distributed with a constant variance. Unfortunately, these conditions are frequently violated with panel data: independence is not satisfied when errors of different units are correlated (cross-sectional dependence), or when errors within each unit are temporarily correlated (serial correlation), or the two cases occur simultaneously. Furthermore, spatial (or network) patterns are an econometric problem which is frequently ignored, although numerous studies of the 
social effects caused by proximity or neighborhood have clearly established that the microdata bases exhibit complex patterns of mutual dependence between cross-sectional units. This is the main econometric problem facing an empirical exercise like ours, since the construction of income microdata bases according to geographical distribution is known to generate a problem of cross-sectional dependence. Additionally, the "identical" distribution of errors does not hold when the variance is not constant (heteroskedasticity). In fact, as we will see further below, both problems are present in our model.

Joint problems of contemporaneous correlation, heteroskedasticity and autocorrelation can be simultaneously solved with Feasible Generalised Least Squares (Parks-Kmenta FGLS approach) or by employing Panel Corrected Standard Errors (Beck and Katz's PCSE method), these methods do work well when the number of years in the sample is at least the same as that of the cross sections considered. ${ }^{15}$ For this reason, the methodology proposed by Driscoll and Kraay (1998), which was developed and adapted to unbalanced panels by Hoechle (2007), is very useful, since it corrects the drawbacks of the previous estimators of the covariance matrix when the cross section dimension is large in relation to the temporal one, as in our case.

We have checked the presence or absence of the aforementioned econometric problems in our estimations and found evidence of significant autocorrelation and heteroskedasticity problems (by way of the Wooldridge test for autocorrelation and the modified Wald test for heteroskedasticity). Additionally, the CD test of Pesaran (2004) adapted by Hoechle (2007) to check if the residuals resulting from the estimations present cross-sectional correlation, allows us to conclude that there is a pattern of dependence in the residuals of the estimated equation. ${ }^{16}$ Therefore, it is necessary to estimate our model with the methodology proposed by Driscoll and Kraay (1998) and adapted to unbalanced panels by Hoechle (2007). This methodology can be used when residuals are non-spherical and it corrects the complex patterns of dependence of the perturbation without requiring the sample employed to present homoskedasticity and

\footnotetext{
${ }^{15}$ See Beck and Katz (1995), Beck (2001), Tosun and Skidmore (2004) and Reed and Webb (2010). Estimated coefficients and standard errors are more robust in the models estimated with Panel Corrected Standard Errors. Feasible Generalised Least Squares generates excessive levels of significance in statistical tests, especially in cases such as ours, when the number of individuals is high in relation to the time dimension of the sample.

${ }^{16}$ The Pesaran test yields values between 0.3 and 0.4 , and thus it is unsurprising that the Pesaran test accepts the existence of cross-sectional dependence, for any level of significance considered.
} 
serial and contemporary uncorrelation. ${ }^{17}$ Moreover, it can be used with a database like ours, since the necessary information is not available in all fiscal years and for all taxpayers. Working with an unbalanced panel allows us to maintain a sufficient number of observations to guarantee the representativeness of the sample. ${ }^{18}$

Results from the models measuring income shifting to capital gains and to movable capital income are shown in Table $2 .{ }^{19}$ Table 3 presents the elasticity of the variables of interest which have proved significant.

Results show that, as expected from a theoretical point of view, taxpayers plan their income on the basis of the tax treatment it receives. Furthermore, total response of movable capital income to changes in the explanatory variables is greater than contemporaneous response, given that, as expected, tax planning presents inertial behaviour, because the lagged endogenous variable is significant and positive. This dynamic component, which captures the speed at which the endogenous variable (movable capital) is adjusted in response to changes in explanatory variables, is close to 1 (0.75), showing that this income adjusts slowly, as the cost of being outside the desired position is small in comparison with the cost of adjustment.

Estimates also indicate that the greater the marginal profit derived from the reduction of taxation for any type of savings income with regard to general income, the greater the weight of savings income in the total tax base, and consequently, the more income the taxpayer shifts from the general base to that of savings. The elasticities of Table 3 show that income shifting is especially sensitive to the tax rates wedge for capital gains $\left(t_{g C G}-\right.$ $\left.t_{S C G}\right)$. Faced with an increase of $100 \%$ in the differential of tax rates, the response of this income is $118.47 \%$. However, the reaction is much lower $(7.76 \%$ contemporaneous response and $31.29 \%$ total effect) for movable capital income. These results are in line with those obtained by Pirtilla and Selin (2011) and Harju and Matikka (2016a) for Finland, although due to the different nature of the Finnish reform they analyse, these

\footnotetext{
${ }^{17}$ We also tested different dynamic panel data formulations, including the maximum verisimilitude approach, and taking logarithms; trying the model in differences; and considering different lags in the variables, although none of these approaches improved the results presented, or passed the Sargan test for instrumental variables or the Arellano-Bond test for autocorrelation.

${ }^{18}$ We considered the possibility of including taxpayer fixed effects which capture the unobserved timeinvariant characteristics of the individuals. However, this procedure is incompatible with the use of weighting assigned to each taxpayer in the calculations to extrapolate the results to the population.

${ }^{19}$ We have also verified the significance of the set of proposed explanatory hypotheses (Wald test).
} 
authors found this shifting effect only among the business owners, obtaining elasticities of around $150 \%$.

Table 2: Estimation of the income shifting model for savings income using the methodology of Driscoll-Kraay

\begin{tabular}{|c|c|c|c|c|}
\hline & \multicolumn{2}{|c|}{ Capitalgains } & \multicolumn{2}{|c|}{ Movablecapital } \\
\hline & Coefficient & $\begin{array}{c}\text { Drisc/Kraay } \\
\text { Std. Err }\end{array}$ & Coefficient & $\begin{array}{c}\text { Drisc/Kraay } \\
\text { Std. Err }\end{array}$ \\
\hline Movablecapital t-1 & & & $0,7517 * * *$ & 0,0207 \\
\hline$\left(\mathrm{t}_{\mathrm{gCG}}-\mathrm{t}_{\mathrm{sCG}}\right)_{\mathrm{t}}$ & $0.1038 * * *$ & 0.0324 & & \\
\hline$\left(t_{\mathrm{gCG}}-t_{\mathrm{sCG}}\right)_{\mathrm{t}} *$ Income $_{\mathrm{t}}$ & $3.37 \mathrm{e}-07 * * *$ & $3.92 \mathrm{e}-08$ & & \\
\hline$\left(t_{\mathrm{gCG}}-t_{\mathrm{sCG}}\right)_{t} *$ Selfemployed $\mathrm{t}_{\mathrm{t}}$ & $0.0759 * * *$ & 0.0078 & & \\
\hline$(\operatorname{tg} M C-\operatorname{tsMC}) \mathrm{t}$ & & & $0.0521 * * *$ & 0.0044 \\
\hline$(\operatorname{tg} M C-\operatorname{tsMC}) t *$ Incomet & & & $-9.52 \mathrm{E}-09$ & $1.50 \mathrm{E}-08$ \\
\hline $\begin{array}{l}(\operatorname{tgMC}-\text { tsMC)t } * \\
\text { Selfemployedt }\end{array}$ & & & $0.0208 * * *$ & 0,0026 \\
\hline$\left(t_{\mathrm{sCG}}{ }^{\mathrm{MC}}-\mathrm{t}_{\mathrm{sCG}}\right)_{\mathrm{t}}$ & -0.0157 & 0.0397 & & \\
\hline $\mathrm{t}_{\mathrm{sCGt}}$ & 0.1096 & 0.1212 & & \\
\hline $\mathrm{tm}_{\mathrm{sMCt}}$ & & & -0.0051 & 0.0080 \\
\hline Year2001 & $-0.2437 * * *$ & 0.0101 & $0.6027 * * *$ & 0.0745 \\
\hline Year2003 & -0.1133 & 0.0869 & $0.1013 * * *$ & 0.0544 \\
\hline Year2005 & -0.0573 & 0.2006 & $0.2427 * * *$ & 0.0368 \\
\hline Year2006 & $0.9512 * *$ & 0.3464 & $0.5403 * * *$ & 0.0394 \\
\hline Year2007 & $-0.7151 * * *$ & 0.1516 & $0.1512 * * *$ & 0.0399 \\
\hline Year2008 & $-1.4805^{* * *}$ & 0.1554 & $0.9788 * * *$ & 0.0238 \\
\hline WeightEA $_{t}$ & $-0.0737 * * *$ & 0.0105 & $-0.0385 * * *$ & 0.0070 \\
\hline WeightEA $_{\mathrm{t}-1}$ & $0.0503 * * *$ & 0.0074 & $0.0342 * * *$ & 0.0059 \\
\hline Mortgageburden $_{\mathrm{t}}$ & -0.0045 & 0.0055 & $-0.0102 * * *$ & 0.0033 \\
\hline Familyburden $_{t}$ & -0.0232 & 0.0210 & -0.01632 & 0.0254 \\
\hline Age $_{t}$ & $0.0550 * * *$ & 0.0082 & $0.06198 * * *$ & 0.0047 \\
\hline Gender $_{t}$ & $-0.4977 * * *$ & 0.0812 & $-0.2877 * * *$ & 0.0277 \\
\hline Status $_{\mathrm{t}}$ & $-0.2123^{* * *}$ & 0.0380 & $-0.1958 * * *$ & 0.0159 \\
\hline Pop $_{t}$ & $0.0990^{* *}$ & 0.0367 & $0.0338 * * *$ & 0.0036 \\
\hline Mediterranean $_{\mathrm{t}}$ & $-0.1258 * * *$ & 0.0379 & 0.0507 & 0.0470 \\
\hline Phousing $_{\mathrm{t}-1}$ & $0.0085^{* * *}$ & 0.0011 & & \\
\hline Trend & $-1.2431 * * *$ & 0.0713 & $-0.1292 * * *$ & 0.0218 \\
\hline Constant & $-9.6110^{* *}$ & 3.706 & $-1.0831 * * *$ & 0.2159 \\
\hline Observations & & 977,763 & & 03,565 \\
\hline $\mathrm{R}^{2}$ & & 0.04 & & 0.63 \\
\hline $\mathrm{F}$ & $\mathrm{F}(22,9)=7$, & $30,916.79$ & $\mathrm{~F}(21,8)=$ & 965.97 \\
\hline Root MSE & & 53.6737 & & 36.68 \\
\hline
\end{tabular}


Table 3: Contemporaneous and total elasticities of the significant variables of interest $\left(^{*}\right)$

\begin{tabular}{|l|c|c|}
\cline { 2 - 3 } \multicolumn{1}{c|}{} & Capital gains & Movable capital \\
\hline $\mathrm{t}_{\mathrm{gCG}}-\mathrm{t}_{\mathrm{sCG}}$ & 1.1847 & \\
\hline $\mathrm{t}_{\mathrm{gMC}}-\mathrm{t}_{\mathrm{sMC}}$ & & 0.0776 \\
& & $0.3129)$ \\
\hline Year2005 & & 0.2427 \\
\hline Year2006 & 0.9512 & 0.5403 \\
\hline Year2007 & -0.7151 & 0.1512 \\
\hline Year2008 & -1.4805 & 0.9788 \\
\hline
\end{tabular}

(*) Total elasticity, derived from the dynamic component of the Movablecapital model, is presented in parentheses.

In addition, when taxpayers have the opportunity to choose their income sources, they take advantage of that opportunity, because income shifting from general income to capital gains motivated by different tax rates $\left(t_{g C G}-t_{s C G}\right)$ increases with taxpayer income (Income), and especially with the status of self-employed or business owner (selfemployed). Income shifting from general income to movable capital is also more marked among the group of self-employed or business owners, although it does not depend on taxpayer income. ${ }^{20}$ The literature has also found a greater response among the business owners group (see Pirttila and Selin, 2011), although most studies are in fact designed to test whether this strategy is found among business owners, since they are the ones who can choose the form of their remuneration. (Kari, 1999; Fjaerli and Lun, 2001; Lindhe et al., 2002 and 2004, Alstadsaeter and Jacob, 2016, Harju and Matikka, 2016a and b).

The results shown by the time dummies suggest that taxpayers anticipated the 2007 tax reform and brought forward the obtaining of movable capital income to 2005, the year when the change in its tax rate was announced. Also, the coefficient obtained for the variable year2006 is, as expected, greater than for year2005, which would indicate that movable capital income was brought forward to 2005 and, above all, to 2006, the year before the reform. Capital gains were only brought forward to 2006, when the capital gains reform was announced, as shown by Year2006.

\footnotetext{
${ }^{20}$ In the Capitalgains model we also interacted the differential of tax rates on savings income, $t_{s C G}{ }^{M C}-t_{s C G}$, with the variables Income and Selfemployed, to test whether the highest-income individuals and selfemployed or business owners are the groups shifting the most income from movable capital to capital gains. The results, which can be supplied on request, support that hypothesis, although the response of the highest-income individuals is significant only at $8 \%$.
} 
In the same way, and in accordance with their planning strategy, once the 2007 reform came into force, taxpayers increased the weight of their movable capital income, which benefited from the reform, and reduced the weight of capital gains, which would be taxed more heavily. These results are supported by the positive sign of year2007 and year2008 in the estimation of movable capital income and the negative sign of these variables in that of capital gains. Similar behaviour was obtained in Chetty and Saez (2005) and Kari et al (2008), for dividend payments; and Dai et al. (2008), Daunfeldt et al. (2010), and Jacob (2012), for capital gains. Also, the coefficient we obtained for the variable year2008 is, as expected, well above that for year2007, due to the learning effect we were trying to capture. Of course, these time dummies might also be capturing other time effects, in addition to the anticipation and learning effects which we are interested in.

The own tax rate of each form of savings income $\left(t_{s C G}\right.$ and $\left.t m_{S M C}\right)$ is not significant in every model, so that taxpayers do not change their reported capital gains or movable capital when its tax rate changes. In line with the interpretation of Harju and Matikka (2016a), our results suggest there would not be a real response by Spanish taxpayers. They would only respond to changes in the differentials of the tax rates. Therefore, all the response would be income shifting.

As Table 2 shows, control variables contribute, in general, to explain the reporting of savings income.

\section{Concluding remarks}

The literature has studied different kinds of tax avoidance or tax planning responses which taxes may induce in economic agents: income shifting over time, between tax bases or between taxpayers, readjustments in financial transactions, etc. In personal income taxation, dual taxes, which tax savings income at lower rates than general income, encourage an income shifting strategy which has hardly been studied by the applied literature. In the Spanish PIT, the difference in rates at which income can be taxed, depending on whether it is obtained as general or savings income, means that taxpayers are encouraged to shift part of their revenues from the general base to that of savings, to take advantage of that more favorable taxation. In the same way, the 
different tax treatment received by capital gains and movable capital can encourage income shifting between both types of savings income.

Based on a model of behavioural response to taxes, and using the Taxpayers Panel of the Institute of Fiscal Studies for the period 1999-2009, in this paper we have tested whether these tax strategies occurred in Spain, where there has traditionally been a favorable tax treatment of capital gains, which was extended from 2007 to the more important savings income, such as dividends and interests. Our results confirm that Spanish taxpayers plan the composition of their taxable base according to the taxation of each income source, and that self-employed or business owners and higher-income individuals make the greatest use of these tax planning strategies. The estimates also indicate that taxpayers shift income over time according to its taxation.

The strategies detected in this paper, like other behavioural responses motivated by taxes, generate inefficiencies and erode the progressivity of the tax system and revenue collection, and thus they must be taken into account when designing taxes. When calculating the optimal tax for labor and capital income, Piketty and Saez (2013) consider (in addition to the redistributive objectives of society) the possibility which taxpayers have to shift earned income into capital income; the greater is the possibility of income shifting ("shifting elasticity"), the closer will be the optimal tax rates for both income types. Although far from the dual tax model, another proposal that limits the opportunities of income shifting is the one contained in the Mirrlees Review (Mirrlees et al., 2010), involving a zero tax rate on the normal return on capital and the taxation of excess returns at the same tax rates as other income. 
ANNEX

Table A1.1: Definition of variables and their expected sign

\begin{tabular}{|c|c|c|}
\hline VARIABLE & DEFINITION & EXPECTED SIGN \\
\hline \multicolumn{3}{|l|}{ Endogenous } \\
\hline Capitalgains & Capital Gains/Total taxable income & \\
\hline Movablecapital & Movable Capital Income/Total taxable income & \\
\hline \multicolumn{3}{|c|}{ Marginal benefit from savings income (tax rate wedge) } \\
\hline $\mathrm{t}_{\mathrm{gCG}}-\mathrm{t}_{\mathrm{sCG}}$ & $\begin{array}{l}\text { Taxpayer marginal benefit derived from the } \\
\text { reduction in taxation for capital gains with respect } \\
\text { to general income }\end{array}$ & + \\
\hline$t_{\mathrm{gMC}}-\mathrm{t}_{\mathrm{sMC}}$ & $\begin{array}{l}\text { Taxpayer marginal benefit derived from the } \\
\text { reduction in taxation for movable capital with } \\
\text { respect to general income }\end{array}$ & + \\
\hline $\mathrm{t}_{\mathrm{sCG}}{ }^{\mathrm{MC}}-\mathrm{t}_{\mathrm{sCG}}$ & $\begin{array}{l}\text { Taxpayer marginal benefit derived from the } \\
\text { reduction in taxation for capital gains with respect } \\
\text { to movable capital income }\end{array}$ & + \\
\hline $\mathrm{t}_{\mathrm{sMC}}{ }^{\mathrm{CG}}-\mathrm{t}_{\mathrm{sMC}}$ & $\begin{array}{l}\text { Taxpayer marginal benefit derived from the } \\
\text { reduction in taxation for movable capital with } \\
\text { respect to capital gains }\end{array}$ & ¿? \\
\hline \multicolumn{3}{|l|}{ Real response } \\
\hline $\mathrm{t}_{\mathrm{sCG}}$ & $\begin{array}{l}\text { Nominal tax rate at which capital gains generated in } \\
\text { more than one year are taxed according to the } \\
\text { regulations of each year }\end{array}$ & - \\
\hline $\operatorname{tmgMC}$ & $\begin{array}{l}\text { Tax rate of movable capital income: three-year } \\
\text { moving average }\end{array}$ & - \\
\hline \multicolumn{3}{|c|}{ Anticipation of the reform } \\
\hline Year2005 & $=1$ in $2005,=0$ the rest & + \\
\hline Year2006 & $=1$ in $2006,=0$ the rest & + \\
\hline \multicolumn{3}{|l|}{ Learning } \\
\hline Year2007 & $=1$ in $2007,=0$ the rest & \multirow{2}{*}{$\begin{array}{l}+ \text { for Movablecapital } \\
\text { - for Capitalgains }\end{array}$} \\
\hline Year2008 & $=1$ in $2008,=0$ the rest & \\
\hline \multicolumn{3}{|c|}{ Opportunity to plan } \\
\hline Income & $\begin{array}{l}\text { Gross income from labor and movable and } \\
\text { immovable capital + net returns from economic } \\
\text { activities + income imputations + capital gains }\end{array}$ & + \\
\hline Selfemployed & $\begin{array}{l}=1 \text { if self-employed or business owner, }=0 \\
\text { otherwise }\end{array}$ & + \\
\hline WeightEA & $=$ Income from economic activities/Income & + \\
\hline \multicolumn{3}{|l|}{ Economic needs } \\
\hline Familyburden & Estimated family burdens & $?$ \\
\hline Mortgageburden & $\begin{array}{l}\text { Annual mortgage (estimated on the basis of the } \\
\text { panel) / Income }\end{array}$ & $?$ \\
\hline \multicolumn{3}{|c|}{ Other control variables } \\
\hline Age & Age of the individual & $\begin{array}{l}\text { - for Movablecapital } \\
\text { + for Capitalgains }\end{array}$ \\
\hline Status & $=1$ if married, $=0$ otherwise & $?$ \\
\hline Gender & $=1$ if male,$=0$ if female & $?$ \\
\hline Pop & $\begin{array}{l}=0 \text { if municipality } \leq 50,000 \text { inhabitants } \\
=1 \text { if } 50,000<\text { municipality } \leq 100,000 \text { inhabitants } \\
=2 \text { if } 100,000<\text { municipality } \leq 500,000 \\
\text { inhabitants } \\
=3 \text { if municipality }>1.000,000 \text { inhabitants }\end{array}$ & $?$ \\
\hline Mediterranean & $\begin{array}{l}=1 \text { if province on Mediterranean coast, }=0 \\
\text { otherwise }\end{array}$ & + \\
\hline Phousing & $\begin{array}{l}\text { Average price of second-hand homes in the country } \\
\text { as a whole }\end{array}$ & + for Capitalgains \\
\hline Trend & $=1$ in $1999,=2$ in $2000 ; \ldots=11$ in 2009 & $?$ \\
\hline
\end{tabular}


Table A1.2. Descriptive statistics

\begin{tabular}{|l|r|r|r|r|}
\hline & \multicolumn{1}{|c|}{ Mean } & $\begin{array}{c}\text { Standard } \\
\text { Error }\end{array}$ & \multicolumn{2}{|c|}{ [95\% Conf. Interval] } \\
\hline \hline Capitalgains & 2.8178 & 0.0129 & 2.7925 & 2.8431 \\
\hline Movablecapital & 7.1661 & 0.0194 & 7.1281 & 7.2042 \\
\hline$t_{g C G}-t_{s C G}$ & 16.0278 & 0.0080 & 16.0121 & 16.0436 \\
\hline$t_{g M C}-t_{s M C}$ & 7.71098 & 0.0103 & 7.6907 & 7.7311 \\
\hline$t_{s C G}{ }^{M C}-t_{s C G}$ & 8.3259 & 0.0128 & 8.3006 & 8.3511 \\
\hline$t_{s M C}{ }^{C G}-t_{s M C}$ & -8.3880 & 0.0129 & -8.4133 & -8.3627 \\
\hline$t_{s C G}$ & 17.4421 & 0.0014 & 17.4392 & 17.4450 \\
\hline$t_{s M C}$ & 27.3197 & 0.0112 & 27.2976 & 27.3419 \\
\hline Income & $84,547.1700$ & 599.2184 & $83,372.7200$ & $85,721.6200$ \\
\hline WeightEA & 4.3001 & 0.0194 & 4.2620 & 4.3381 \\
\hline Mortgageburden & 5.1263 & 0.0173 & 5.0924 & 5.1603 \\
\hline Familyburden & 1.3270 & 0.0016 & 1.3237 & 1.3303 \\
\hline Age & 53.5907 & 0.0178 & 53.5557 & 53.6257 \\
\hline Gender & 0.7216 & 0.0005 & 0.7204 & 0.7227 \\
\hline Status & 0.7462 & 0.0005 & 0.7451 & 0.7473 \\
\hline Pop & 1.3394 & 0.0015 & 1.3363 & 1.3425 \\
\hline Mediterranean & 0.4724 & 0.0006 & 0.4712 & 0.4737 \\
\hline Phousing & $1,888.6310$ & 0.4082 & $1,887.8300$ & $1,889.4310$ \\
\hline
\end{tabular}




\section{Table A1.3 Correlations}

\begin{tabular}{|c|c|c|c|c|c|c|c|c|c|c|c|c|c|c|c|c|c|}
\hline & $\mathrm{tg}_{\mathrm{gCG}}-\mathrm{t}_{\mathrm{sCG}}$ & $\mathrm{t}_{\mathrm{scG}}{ }^{\mathrm{MC}-\mathrm{t}_{\mathrm{sCG}}}$ & $\mathrm{tg}_{\mathrm{gcG}}$ & $\operatorname{tgMC}_{\mathrm{gMC}}-\mathrm{t}_{\mathrm{sMC}}$ & $\mathrm{t}_{\mathrm{sMC}} \mathrm{CG}_{-} \mathrm{t}_{\mathrm{sMC}}$ & $\mathrm{tm}_{\mathrm{sMC}}$ & Income $_{t}$ & Selfemployed & WeightEA & Mortgageburden & Familyburden & Age & Gender & Status & Pop & Mediterranean & Phousing \\
\hline $\mathrm{tgCG}_{\mathrm{g}}-\mathrm{t}_{\mathrm{sCG}}$ & 1.0000 & & & & & & & & & & & & & & & & \\
\hline $\mathrm{t}_{\mathrm{sCG}} \mathrm{MC}_{-} \mathrm{t}_{\mathrm{sCG}}$ & 0.6030 & 1.0000 & & & & & & & & & & & & & & & \\
\hline $\mathrm{tgCG}_{\mathrm{gCG}}$ & -0.2687 & -0.5308 & 1.0000 & & & & & & & & & & & & & & \\
\hline $\mathrm{tg}_{\mathrm{g} M C}-\mathrm{t}_{\mathrm{s} M \mathrm{C}}$ & 0.0243 & -0.7805 & 0.4545 & 1.0000 & & & & & & & & & & & & & \\
\hline $\mathrm{t}_{\mathrm{s} M \mathrm{MC}^{\mathrm{CG}}-\mathrm{t}_{\mathrm{s} M C}}$ & -0.5893 & -0.9943 & 0.5127 & 0.7841 & 1.0000 & & & & & & & & & & & & \\
\hline $\mathrm{tm}_{\mathrm{sMC}}$ & 0.6615 & 0.9130 & -0.3851 & -0.6253 & -0.9161 & 1.0000 & & & & & & & & & & & \\
\hline Income $_{t}$ & 0.1751 & 0.0799 & -0.0224 & 0.0367 & -0.0797 & 0.1047 & 1.0000 & & & & & & & & & & \\
\hline Selfemployed & 0.0370 & -0.0052 & 0.0130 & 0.0353 & 0.0057 & -0.0033 & 0.0216 & 1.0000 & & & & & & & & & \\
\hline WeightEA & 0.0374 & -0.0081 & 0.0075 & 0.0391 & 0.0082 & -0.0064 & 0.0177 & 0.6071 & 1.0000 & & & & & & & & \\
\hline Mortgageburden & -0.1048 & 0.0128 & -0.0074 & -0.0985 & -0.0165 & -0.0040 & -0.0356 & -0.0461 & -0.0016 & 1.0000 & & & & & & & \\
\hline Familyburden & -0.0015 & -0.0013 & -0.0380 & 0.0005 & 0.0008 & -0.0074 & 0.0007 & 0.0088 & 0.0181 & -0.0360 & 1.0000 & & & & & & \\
\hline Age & 0.1242 & -0.0435 & -0.0157 & 0.1536 & 0.0545 & -0.0322 & 0.0248 & 0.0724 & 0.0163 & -0.2758 & 0.0825 & 1.0000 & & & & & \\
\hline Gender & 0.1407 & 0.0415 & -0.0006 & 0.0569 & -0.0446 & 0.0656 & 0.0253 & 0.0995 & 0.0569 & -0.0428 & 0.0103 & 0.0235 & 1.0000 & & & & \\
\hline Status & 0.0788 & 0.0122 & 0.0112 & 0.0455 & -0.0139 & 0.0271 & 0.0123 & 0.0549 & 0.0354 & -0.0474 & 0.1555 & -0.0103 & 0.3032 & 1.0000 & & & \\
\hline Pop & 0.2220 & 0.1129 & -0.0228 & 0.0327 & -0.1103 & 0.1400 & 0.0571 & -0.1167 & -0.0667 & -0.0282 & -0.0131 & 0.0664 & -0.0633 & -0.0654 & 1.0000 & & \\
\hline Mediterranean & -0.0203 & -0.0065 & 0.0030 & -0.0077 & 0.0061 & -0.0097 & -0.0074 & -0.0154 & -0.0094 & 0.0150 & -0.0011 & -0.0347 & -0.0146 & -0.0102 & -0.1005 & 1.0000 & \\
\hline Phousing & -0.1124 & -0.5449 & $\mid-0.2098$ & 0.5946 & 0.5502 & -0.4628 & 0.0028 & 0.0125 & 0.0169 & -0.0794 & 0.0597 & 0.1481 & 0.0042 & 0.0148 & -0.0325 & -0.0076 & 1.0000 \\
\hline
\end{tabular}




\section{References}

Alstadsæter, A. and M. Jacob (2016): "Dividend taxes and income shifting" The Scandinavian Journal of Economic, 118 (4): 693-717.

Attanasio, O. P. and M. Browning (1995): "Consumption over the Life Cycle and over the Business Cycle", American Economic Review, 85 (5): 1118-1137.

Attanasio, O. and G. Weber (2010):“Consumption and Saving: Models of Intertemporal Allocation and Their Implications for Public Policy", Journal of Economic Literature, 48: 693-751.

Auerbach, A. J., L. E. Brumany and J. M. Siegel (1998): "Capital gains taxation and tax avoidance: new evidence from panel data”, NBER Working Paper 6399, National Bureau of Economic Research.

Auerbach, A. J. and J. M. Siegel (2000): "Capital-gains realizations of the rich and sophisticated”, American Economic Review, 90: 276-282.

Beck, N. (2001): "Time-Series-Cross-Section Data: What Have We Learned in the Past Few Years?", Annual Review of Political Science, 4: 271-93.

Beck, N. and J. N. Katz (1995): "What to do (and not to do) with Time-series Crosssection Data", The American Political Science Review, 89 (3): 634-647.

Boadway, R. (2004): "The Dual Income Tax System - An Overview", CESifo DICE Report, 3: 3-8.

Carroll, C. D. (1997): "Buffer-Stock Saving and the Life Cycle/Permanent Income Hypothesis", Quarterly Journal of Economics, 112 (1): 1-55.

Chetty, R. and E. Saez (2005): "Dividend taxes and corporate behavior: Evidence from the 2003 dividend tax cut", Quarterly Journal of Economics, 120 (3):791-833.

Christiansen, V. and M. Tuomala (2008): "On taxing capital income with income shifting”, International Tax and Public Finance, 15: 527-547.

Dai, Z., E. Maydew, D. A. Shackelford and H. Zhang (2008): "Capital Gains Taxes and Asset Prices: Capitalization or Lock-In?”, Journal of Finance, 63 (2): 709-742.

Daunfeldt, S., U. Praski-Ståhlgreny and N. Rudholm (2010): "Do high taxes lock-in capital gains? Evidence from a dual income tax system" Public Choice, 145: 25-38.

De Mooij, R. and G. Nicodème (2008): "Corporate tax policy and incorporation in the EU”, International Tax and Public Finance, 15: 478-498.

Dirección General de Tributos, General Directorate of Taxes (2007): El Impuesto sobre la Renta de las Personas Físicas y el Impuesto sobre el Patrimonio en 2004. Análisis de los datos estadísticos del ejercicio, Madrid: Ministerio de Economía y Hacienda. (http://www.minhafp.gob.es/Documentacion/Publico/Tributos/Estadisticas/IRPF_IP/ 2004/Analisis_estadistico_IRPF_IP_2004.pdf).

Dirección General de Tributos, General Directorate of Taxes (2008): El Impuesto sobre la Renta de las Personas Físicas y el Impuesto sobre el Patrimonio en 2005. Análisis de los datos estadísticos del ejercicio, Madrid: Ministerio de Economía y Hacienda. (http://www.minhafp.gob.es/Documentacion/Publico/Tributos/Estadisticas/IRPF_IP/ 2005/Analisis_estadistico_IRPF_IP_2005.pdf). 
Dirección General de Tributos, General Directorate of Taxes (2009): El Impuesto sobre la Renta de las Personas Físicas y el Impuesto sobre el Patrimonio en 2006. Análisis de los datos estadísticos del ejercicio, Madrid: Ministerio de Economía y Hacienda. (http://www.minhafp.gob.es/Documentacion/Publico/Tributos/Estadisticas/IRPF_IP/ 2006/Analisis_estadistico_IRPF_IP_2006.pdf).

Dirección General de Tributos, General Directorate of Taxes (2010): El Impuesto sobre la Renta de las Personas Físicas y el Impuesto sobre el Patrimonio en 2007. Análisis de los datos estadísticos del ejercicio, Madrid: Ministerio de Economía y Hacienda. (http://www.minhafp.gob.es/Documentacion/Publico/Tributos/Estadisticas/IRPF_IP/ 2007/Analisis_estadistico_IRPF_IP_2007.pdf).

Dirección General de Tributos, General Directorate of Taxes (2011): El Impuesto sobre la Renta de las Personas Físicas en 2008. Análisis de los datos estadísticos del ejercicio, Madrid: Ministerio de Economía y Hacienda.

(http://www.minhafp.gob.es/Documentacion/Publico/Tributos/Estadisticas/IRPF/200 8/Analisis_estadistico_IRPF_2008.pdf).

Dirección General de Tributos, General Directorate of Taxes (2012): El Impuesto sobre la Renta de las Personas Físicas en 2009. Análisis de los datos estadísticos del ejercicio, Madrid: Ministerio de Hacienda y Administraciones Públicas.

(http://www.minhafp.gob.es/Documentacion/Publico/Tributos/Estadisticas/IRPF/2009/Anali sis_estadistico_IRPF_2009.pdf).

Domínguez-Barrero, F. and J. López-Laborda (2001): "Principios de planificación fiscal", Papeles de Economía Española, 87: 335-345.

Domínguez-Barrero, F. and J. López-Laborda (2003): "Planificación fiscal con el impuesto lineal”, Cuadernos Aragoneses de Economía, 2a época, 13 (1): 87-108.

Domínguez-Barrero, F. and J. López-Laborda (2008): "Planificación fiscal con el impuesto dual sobre la renta", Revista de Economía Aplicada, 16 (48): 89-110.

Domínguez-Barrero, F., J. López-Laborda and F. Rodrigo-Sauco (2005):“¿Afectan el IRPF y el Impuesto sobre Sociedades a la elección de la forma de empresa?", Hacienda Pública Española/Revista de Economía Pública, 174: 55-86.

Driscoll, J. C. and A. C. Kraay (1998): "Consistent Covariance Matrix Estimation with Spatially Dependent Panel Data", Review of Economics and Statistics, 80: 549-560.

Fjaerli, E. and D. Lund (2001):"The Choice between Owner's Wage and Dividends under the Dual Income Tax", Finnish Economic Papers, 14: 104-119.

Gomes, F. and A. Michaelides (2005): "Optimal Life-Cycle Asset Allocation: Understanding the Empirical Evidence”, Journal of Finance, 60 (2): 869-904.

Gordon, R. H. and J. K. Mackie-Mason (1994): "Tax Distortions to the Choice of Organizational Form", Journal of Public Economics, 55: 279-306.

Gordon, R.H. and J. B. Slemrod (2000): “Are "real" responses to taxes simply income shifting between corporate and personal tax base?", in J. Slemrod, ed., Does Atlas shrug? The economic consequences of taxing the rich Cambridge: Harvard University Press, Russel Sage Foundation, pp. 240-288.

Gourinchas, P. O. and J. A. Parker (2002): "Consumption over the Life Cycle", Econometrica, 70 (1): 47-89. 
Harju, J. and T. Matikka (2016a): "The Elasticity of Taxable Income and IncomeShifting: What is 'Real' and What is Not?", International Tax and Public Finance 23 (4): 640-669.

Harju, J. and T. Matikka (2016b): "Business owners and income-shifting: evidence from Finland", Small Business Economics 46 (1): 115-136.

Hoechle, D. (2007): "Robust standard errors for panel regressions with cross-sectional dependence", Stata Journal, 7(3): 281-312.

Ivkovich, Z., J. M. Poterba and S.Weisbenner (2005): "Tax-Motivated Trading by Individual Investors", American Economic Review, 95 (5): 1605-1630.

Jacob, M. (2016a): "Tax Regimes and Capital Gains Realizations", European Accounting Review, online, http://dx.doi.org/10.1080/09638180.2016.1203811

Jacob, M. (2016b): “Cross-Base Tax Elasticity of Capital Gains”, Applied Economics 48(28):2611-2624.

Jacob, M. and M. Jacob (2012): "Taxation, Dividends, and Share Repurchases: Taking Evidence Global”, Journal of Financial and Quantitative Analysis, 48 (4): 12411269.

Kari, S. (1999): Dynamic Behaviour of the Firm under Dual Income Taxation. Helsinki: Helsinki School of Economics and Business Administration..

Kari, S.; H. Karikallio and J.Pirttilä (2008): “Anticipating Tax Changes: Evidence from the Finnish Corporate Income Tax Reform of 2005”, Fiscal Studies 29 (2): 167-196.

Le Maire, D. and B. Schjerning. (2013): Tax bunching, income shifting and selfemployment. Journal of Public Economics, 107: 1-18.

Lindhe, T., J. Södersteny and A.Öberg (2002): "Economic Effects of Taxing Closed Corporations under a Dual Income Tax", IfoStudien, 48: 575-610.

Lindhe, T., J. Södersten and A.Öberg (2004): "Economic Effects of Taxing Different Organizational Forms under the Nordic Dual Income Tax", International Tax and Public Finance, 11: 469-485.

López-Laborda, J. and A. Zárate-Marco (1999): "IRPF, familia e incentivos, Una propuesta metodológica y una aplicación", Hacienda Pública Española, 151: 27-41.

Mirrlees, J. (pres.), S. Adam, T. Besley, R. Blundell, S. Bond, R. Chote, M. Gammie, P. Johnson, G. Myles y J. Poterba, eds. (2010): Dimensions of Tax Design. The Mirrlees Review, Oxford: Oxford University Press.

Moreno Cepas, M. C. (2012): "Un análisis de los efectos de la diferencia entre los tipos generales y del ahorro sobre la composición de la base imponible del IRPF”, Trabajo Fin de Máster (dir. Julio López-Laborda), Universidad de Zaragoza.

Onrubia, J., F. Picos and C. Pérez (2011): Panel de declarantes del IRPF 1999-2007: Diseño, metodología y guía de utilización, Madrid: Instituto de Estudios Fiscales.

Onrubia, J., F. Picos, C. Pérez, C. Gallego, M. C. González and S. Huete (2012): "Panel de declarantes del IRPF 1999-2008: Metodología, estructura y variables", Documentos, 12/2012, Madrid: Instituto de Estudios Fiscales.

Pesaran, M. (2004): "General Diagnostic Tests for Cross Section Dependence in Panels", Cambridge Working Papers in Economics, 435, Faculty of Economics, University of Cambridge. (https://doi.org/10.17863/CAM.5113) 
Piketty, T. and E. Saez (2013): “Optimal Income Labor Taxation”, in A. J. Auerbach, R. Chetty, M. Feldstein and R. Sáez, eds., Handbook of Public Economics, vol. 5, Amsterdam: North-Holland, pp. 391-474.

Piketty, T., E. Saez y S. Stantcheva (2014): “Optimal Taxation of Top Labor Incomes: A Tale of Three Elasticities", American Economic Journal: Economic Policy, 6 (1): 230-271.

Pirttila, J. and H. Selin (2011): "Income shifting within a dual income tax system: Evidence from the Finnish Tax Reform of 1993", Scandinavian Journal of Economics, 113 (1): 120-144.

Pirttila, J.; S. Kari and H. Karikallio (2008): "Anticipating Tax Changes: Evidence from the Finnish Corporate Income Tax Reform of 2005". Fiscal Studies 29(2):167-196.

Poterba, J. M. (1987): “How burdensome are capital gain taxes?", Journal of Public Economics, 33: 157-172.

Poterba, J. M. and S. J. Weisbenner (2001): "Capital Gains Tax Rules, Tax-loss Trading, and Turn-of-the-year Returns", Journal of Finance, 56: 353-367.

Reese, W. A. (1998): "Capital Gains Taxation and Stock Market Activity: Evidence from IPOs", Journal of Finance, 53 (5): 1799-1819.

Reed, W. R. and R. Webb (2010): "The PCSE estimator is good, just not as good as you think", Journal of Time Series Econometrics, 2 (1): article 8.

Saez, E., J. B. Slemrod and S. H. Giertz, (2012): "The Elasticity of Taxable Income with Respect to Marginal Tax Rates: A Critical Review", Journal of Economic Literature, 50: 3-50.

Saez, E. and S. Stantcheva (2016): "A Simpler Theory of Optimal Capital Taxation", NBER Working Paper 22664, National Bureau of Economic Research.

Slemrod, J. B. (2001): "A general model of the behavioral response to taxation", International Tax and Public Finance, 8: 119-128.

Sørensen, P. B. (2005): “Dual Income Taxation: Why and How?”, FinanzArchiv, 61: 559-586.

Sørensen, P. B. (2010): "Dual income taxes: A Nordic tax system", in I. Claus, N. Gemmell, M. Harding and D. White (eds.), Tax reform in open economies, Cheltemham, UK: Edward Elgar, pp.78-108.

Stephens, M. Jr. and J. Ward-Batts (2004): "The impact of separate taxation on the intra-household allocation of assets: evidence from the UK", Journal of Public Economics, 88: 1989-2007.

Thoresen, T. O. and A. Alstadsæter (2010): "Shifts in Organizational Form under a Dual Income Tax System", FinanzArchiv/Public Finance Analysis, 66: 384-418.

Tosun, M. S. and M. Skidmore (2004): "Interstate Competition and Lottery Revenues", National Tax Journal, 57 (2): 163-178. 